\title{
ENGLISH VOICE AND ITS PROSODIC CHARACTERISTICS IN TEACHING ORAL INTERPRETATION
}

\author{
Tetiana Yeremenko, Angelina Demchuk, Iryna Lukyanchenko \\ State institution "South Ukrainian National Pedagogical University \\ named after K. D. Ushynsky”, Odesa, Ukraine \\ germfil.inyaz@gmail.com
}

\begin{abstract}
The research concerns the problem of mastering English voice production skills in oral interpretation of the authentic belles-lettres texts. The purpose of the paper is to present the teaching algorithm of training future English language and literature teachers' skills in decoding and orally interpreting verbalised English voice prosodic characteristics. The authors argue the necessity of training future English teachers in mastering their voices on the basis of the mechanism of English voice perception in order to make them sound English. The research represents the results of experimental teaching English voice production skills to the $4^{\text {th }}$ year BA students at South-Ukrainian National Pedagogical University named after K. D. Ushynsky. The participants were 60 students - future English language and literature teachers - who agreed to take part in the research. Data analysis tools comprise pedagogical observation, questionnaires, testing for skills level assessment, expert assessment of testing results, statistical and mathematical processing of obtained data. The experimental teaching included three stages: diagnostic (entry testing), empirical training (teaching algorithm implementation) and checkout (final testing). The obtained results prove that the suggested four-stepped teaching algorithm in "Oral interpretation of the text" successfully starts in students the mechanism of the English voice perception, develops their ability to decode verbalised English voice prosodic characteristics and their functions in the process of philological reading, and forms future English language and literature teachers' specific skills in English voice modulation in oral interpretation.
\end{abstract}

Keywords: English voice; verbalised prosodic characteristics; teaching algorithm; mechanism; oral interpretation; philological reading; pre-service English language and literature teachers.

\section{Introduction}

Oral interpretation as well as philological reading of the belles-lettres texts is an integral part of foreign language professional teaching. It is clear that oral interpretation demands specific skills of voice production in students of foreign language department, especially pre-service English teachers. However, practically no attention is paid to the voice and its prosodic characteristics as to the crucial tool of the English language acquisition. Hence a pivotal problem of teaching oral interpretation is how to train students in mastering their voices in order to make them sound English.

Oral interpretation is understood as a process of profound studying a work of literary art and performing it to an audience (Klug, 2015). The main goal of oral interpretation is to render the author's intentions by decoding their background, viewpoints, time and conditions that influenced the literary work. Oral interpretation is a vocal expression of the meaning of literary works that actually means to analyse the text in order to provide insights into its images, symbols, reveal its characters, and finally communicate the results of the analysis using a voice. In this connection, it has become obvious that oral interpretation is closely interwoven with philological reading as oral interpretation is impossible without philological experience.

Philological reading as a kind of specific reading aimed at reprocessing philological information of a foreign language text (Perlova, 2016). It is considered to be a component of a philologist's professional training and involves profound interpretation of a foreign language text, all its implications, nuances, connotations, cultural references, and existential concepts (Kain, 1998; Perlova, 2015) which are accumulated and form the philological experience that is sufficient to solve professional communicative tasks. Philological reading as an accumulator of philological experience includes all the aspects of a foreign language: phonetic, lexical and grammatical ones, and, as Kain (1998) claims, may aim at analysing either all striking features of the text or its selected features.

Thus, in one of the aspects, philological reading as a linguistic issue demands knowledge and skills of decoding and interpreting prosodic images of belles-lettres texts. Prosodic image is a complex of prosodic characteristics evoking readers' or listeners' associations either with outer world phenomena (outer prosodic image) or inner feelings and emotions (inner prosodic image) (Yakovleva, 1998). To orally interpret prosodic images of a belles-lettres text students should be able to use appropriate prosodic means. The effectiveness of prosodic means employment depends on students' lexical competence that involves specific

(C) Tetiana Yeremenko, Angelina Demchuk, Iryna Lukyanchenko. 2020. Published by Igor Sikorsky Kyiv Polytechnic Institute. This is an Open Access article distributed under the terms of the licence CC BY 4.0 
vocabulary knowledge (Rabiah, 2020), i.e. the first step in philological reading and further oral interpretation procedures implies obligatory lexical awareness of prosodic characteristics verbalisation means.

In our previous research, we studied verbalisation of the voice prosodic characteristics in the modern English language (Demchuk, 2009, 2015). We have proved that lexical units verbalise voice prosodic characteristics (speech melody, loudness, tempo, voice quality) on the level of semes (to chirp, high, to shout, to blurt), sememes (loud, soft, hoarse, husky) and word-combinations (little voice, unsteady voice), separately and in various combinations of two (to snap, to shriek, to murmur, to grumble), three (to bellow, to bark, to growl) or four parameters (to rumble, rumbling). Means of verbalisation of the voice prosodic characteristics in English form an independent layer of the vocabulary that constructs a definite fragment of the English linguistic world picture. Verbal combinatory, unlike seme combinations, manifests itself when one or more prosodic characteristics are verbalised in several verbal units (to whisper huskily, to bark loudly, to pant hoarsely). In the belles-lettres texts, the means of the prosodic parameters verbalisation fulfil a characterological function which is realised in constant and situational characteristics of a personage's voice. Constant voice characteristics identify speakers' gender, age, nationality, profession and reflect their outer and inner qualities. Situational ones represent emotional voice verbalisation and can be realised only in the emotionally charged situations.

It is obvious that voice production varies in different language communities. Studying biophysical basis of voice production, physico-acoustical effect of this basis realisation in complex with psychoacoustical impression from the speaking voice in a given foreign language, Medvedeva (1988) introduced such a notion as "national voice type". She claimed that the prosodic characteristics of decreased loudness, wide pitch range and muffled voice quality play a pivotal role in distinguishing English voice from the others (cited by Demchuk, 2009). Thus, the research proves that English speaking voice is a unity of definite prosodic parameters, possessing its specificity of sounding. It sustains the fact that English voice production demands specific skills in voice modulation from non-native English speakers. We believe that philological reading may serve as a significant tool for developing future English teachers' abilities to produce and modulate their voices as close to the English voice as possible in the process of philological reading by starting perceptual and cognitive mechanisms of English voice perception. Basing on Belin's model of voice perception (Belin et al., 2004) in our interpretation the perceptual and cognitive processes of the English voice perception include general auditory analysis of the voice prosodic characteristics, recognition of voice prosodic characteristics and their verbalisation means in the English language, analysis of speech information (vocal or written), vocal affect analysis (decoding emotional states conveyed by voice), analysis of vocal identity, i.e. decoding speaker's personal information (age, gender, nationality, etc.) by voice characteristics.

Thus, the purpose of the paper is to present the algorithm of training pre-service English language and literature teachers' skills in decoding and orally interpreting verbalised English voice prosodic characteristics. To achieve the purpose, the following objectives were set:

(1) to teach university students to decode verbalised vocal cues in the authentic belles-lettres texts;

(2) to train pre-service English language and literature teachers to produce and modulate their voices on the basis of the mechanism of English voice perception;

(3) to assess the efficacy of the suggested teaching algorithm in developing specific skills in English voice modulation for oral interpretation.

It was hypothesised that suggested teaching algorithm would result in a considerable increase of the students' specific proficiency in the English voice production.

\section{Methods}

Research design

The study involved the use of mixed (quantitative and qualitative) data assessment. The research data were collected using questionnaires, testing for skills level assessment, expert assessment of testing results, statistical and mathematical processing of obtained data, pedagogical observation. The quantitative methods were applied to indicate the levels of students' specific skills in English voice modulation for oral interpretation. Questionnaires were offered for students' self-assessment to clarify their view of their own achievements in the English voice production, being used to corroborate the data provided by test results. The qualitative research method (pedagogical observation) showed how the educational effect was realised.

\section{Participants}

The participants were 60 BA undergraduate students of the Department of Foreign Languages, SouthUkrainian National Pedagogical University named after K. D. Ushynsky. The study was conducted in the form of natural experimental teaching, which lasted over the second semester of 2018-2019 academic year. 
Being natural, teaching implied no artificial intervention, excluded intentional selection of students. All students agreed to participate in the research on their free will.

The researchers ( 3 in number) acted as both facilitators and observers, focusing on training students' specific skills in decoding and orally interpreting verbalised English voice prosodic characteristics as part of their training in disciplining the voice for the professional purpose as an English language and literature teacher.

\section{Instruments and procedure}

The experimental teaching included the following stages: (1) diagnostic (entry testing), (2) empirical training (teaching algorithm implementation) and (3) checkout (final testing).

Students were randomly divided into equal in number groups EG 1 and EG 2. Group EG 1 and EG 2 studied within the same stages, the difference was as follows: students of EG 1 were suggested a wider communicative context, analysis of the lexical units that verbalise various combinations of voice prosodic characteristics with their graphical representation (graphic bubble schemes); students of EG 2 worked with narrow communicative context, tasks for graphical representation were not involved. The groups were not informed about the differences in their activities.

The aim of the first stage was to determine the level of students' skills to recognise the means of verbalisation of the English voice prosodic characteristics in authentic belles-lettres texts, to define their function and employ appropriate prosodic means in oral interpretation.

The entry test included two tasks. In Task 1 the students were offered to decode the prosodic characteristics implied by the authors' remarks in the English belles-lettres fragments and read the fragment out conveying the emotions by modulating their voices according to the author's remarks. What follows is an example of the fragments: "I don't remember which guard was sitting at the duty desk that day - one of the floaters, I guess - but Percy must not have liked the way he looked, because he growled, "You wipe that smirk off your shitpoke face or I'll wipe it off for you" as he went by" (King, 1999, p. 46). In Task 2 students were to orally interpret the given excerpts paying attention to the constant characteristics of the personages' voices, for example: "Hello, Bridget, this is Colin Firth" It was Mr. Darcy. The same posh, deep, can't-bebothered voice that he proposed to Elizabeth Bennet in on the BBC. "I gather you are going to Rome to interview me on Monday," he went on, "I was calling to arrange somewhere to meet. There is a square called the Piazza Navona. I'll meet you about 4/30 by the fountain" (Fielding, 2015, p. 248).

Students' answers were recorded. Experts (researchers) were to assess these answers according to the following criteria: task assessment (the ability to recognise English voice prosodic characteristics in oral speech and the means of their verbalisation in the belles-lettres texts); prosodic appropriateness (that of voice prosodic characteristics - loudness, speech melody, voice quality, tempo); voice adaptability (the ability to modulate one's voice in accordance with functional peculiarities of voice prosodic characteristics: either constant or situational ones).

The aim of the empirical training was to develop students' abilities to decode verbalised voice prosodic characteristics and their functions in the belles-lettres discourse in order to employ appropriate prosodic means in oral interpretation. For this purpose, we created a teaching algorithm that was implemented in the educational process within the course "Oral interpretation of the text".

The algorithm consisted of the following steps: (1) teacher's introduction; (2) analytical skills formation; (3) productive skills formation; (4) integrated practice.

Step 1 was aimed at providing students with basic knowledge about English voice, its prosodic characteristics and means of their verbalisation. For this purpose, the following salient points were discussed at the lectures: notions of voice, speaking voice and their differences; English voice as a complex unity of the prosodic characteristics (loudness, speech melody, voice quality, and tempo); means of verbalisation of the speaking voice prosodic characteristics as an independent layer of the vocabulary that constructs a definite fragment of the English linguistic world picture; the semantic peculiarities of the lexical units verbalising a single prosodic characteristic (to holler, to whisper - loudness; high-pitched, to sing-song, abruptly, monotonous - melody; hoarse, tremulous, throaty, resonant - voice quality; to rattle, slowly - tempo) and the combinations of two (to croon - low pitch + decreased loudness), three (to bark - high pitch + increased loudness + quickened tempo) or four parameters (to rumble - low pitch + increased loudness + duration + deep voice quality); a characterological function of the verbalised prosodic parameters in the belles-lettres discourse and the ways of its actualisation by situational and constant characteristics of a personage's speaking voice.

It is noteworthy that following Derry's (1990) cognitive model of learning, our goal was to help students combine their prior knowledge with the new one, and provide them with the means of expressing new notions. Thus, we started from reminding students about the voice prosodic characteristics (loudness, 
speech melody, voice quality, and tempo) and involved them in building new knowledge by asking leading questions, by reading and discussing text fragments. The purpose was to demonstrate the students that, on the one hand, situational characteristics represent the emotional voice and can be realised only in the emotionally charged situations; on the other hand, that constant characteristics identify speakers' gender, age, nationality, profession and reflect their outer and inner qualities. Students' special attention was focused on the fact that speaking voice prosodic characteristics in the English language are verbalised by the definite linguistic means. Thus, the students of EG 1 were provided with the basic list of 56 words (verbs, adjectives, adverbs, and nouns) that nominate loudness (to cry, to shout, to whisper; loud, strong, soft, quiet; loudly, quietly, softly; hiss, etc.), speech melody (to snarl, to screech; harsh, shrill, flat; sharply, abruptly, mildly; monotone), voice quality (to tremble, to slur; hoarse, unsteady, casual, clear, strangled, breathy; hoarsely, shakily, casually, eagerly; twang), tempo (to spit, to drawl; slow, drawling; quickly, hastily) and their combinations (to twitter, to croak, to ring, to rap, to groan, to bellow, to bark, to growl, to rumble) in the English language. Unlike the students of EG 1, the students of EG 2 were provided with the basic list of 24 lexical units nominating only single prosodic characteristics (6 words for each parameter).

To make the material comprehensible and accessible we used graphic schemes that helped us explain the semantic structure of the lexical units verbalising two and more prosodic parameters, clearly demonstrate which semantic components are combined in the sememe to nominate a definite combination of the prosodic characteristics. The example of such graphic schemes is presented below in Figure 1:

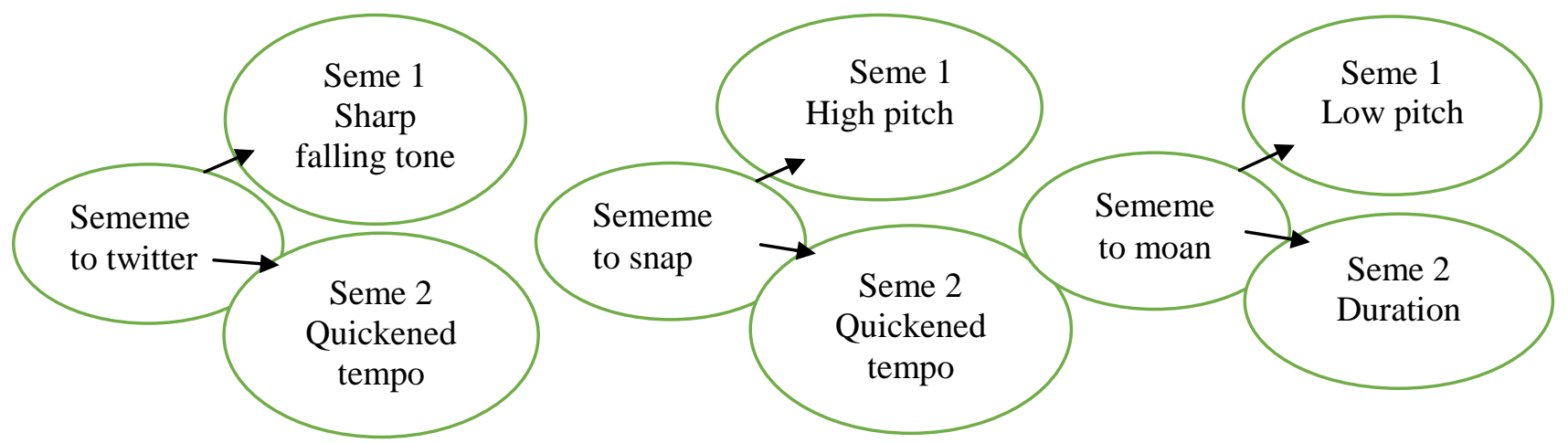

Figure 1. Schemes of verbalised prosodic characteristics combinations

The schemes illustrate various types of speech melody + tempo combinations. For instance, "to twitter" verbalises the combination of high pitch ("high") and quickened tempo ("quick"); "to snap" - the combination of sharp falling tone ("sharply") and quickened tempo ("quick"); "to moan" - the combination of low pitch ("low") and the duration of sounding ("long"), and so on.

As mentioned above, analysis is an inalienable part of the cognitive processes of the English voice perception. Thus, the aim of Step 2 was to form students' abilities to recognise, identify and decode verbalised vocal cues. They were to work with the belles-lettres texts by the famous English writers to find the means of verbalisation of the English voice prosodic characteristics; to decode single prosodic characteristics (loudness, melody, voice quality, tempo) and their combinations implied in the author's remarks; to define the function of verbalised prosodic characteristics and their combinations in the English belles-lettres texts. At this Step, we offered the students two types of tasks.

The first type implied the analysis of semantics of the verbalised voice prosodic characteristics and their combinations, for example: scan 3 short stories of your favourite author in order to find the verbalisation means of loudness, melody, voice quality, tempo (consult the dictionary if necessary) and compile the authors vocabulary of verbalised voice prosodic characteristics; read the given extracts from the belleslettres texts paying attention to the authors' descriptions of personages' voices, define what prosodic characteristics or their combinations are verbalised.

As a part of Step 2, activities students were asked to enlarge the suggested basic lists of words on the basis of the analysed texts. In order to stimulate their cognitive processes, we asked students of EG 1 to choose 15 words in each list, analyse the semantic components of the lexical units nominating various combinations of voice prosodic characteristics and present them in the form of graphic bubble schemes. Unlike the students of EG 1, the students of EG 2 were not to do tasks for graphical representation.

The tasks of the second type are focused on the analysis of the speaking voice functional peculiarities, i.e. situational and constant characteristics, for instance: read the given text fragment and identify the emotional state of the character conveyed by characters' voice prosodic characteristics paying attention to 
the context of the speech situation (linguistic and extralinguistic factors); analyse the given text fragment and find the correlations between the characters' emotional states and their voice prosodic characteristics; read the given text fragment and comment on the personages' voice characteristics as indicators of their gender, age, profession or nationality. For example, analysing the excerpt 'That's all I bloody need,' snarled Perdita. Daisy blushed. 'I'm sorry to barge in,' she faltered. 'I just came to see how Luke was. How are you?' (Cooper, 1992, p. 481) the students found out that in this communicative situation the character expresses confusion speaking in a low, quivering voice that is verbalised by the verb "to falter".

It is noteworthy that in our work in Step 2 we made emphasis on the analysis of the means of verbalisation of the English voice prosodic characteristics in both written and oral discourse. Thus, for analysis students were also recommended extracts from audio books or film adaptations of the famous English writers.

Step 3 focused on developing students' skills to convey the emotional states in English by modulating their voices; to adjust their voice prosodic parameters and their combinations according to the given social or psycho-physical characteristics. The students were to orally interpret the excerpts from the belles-letters texts doing the following tasks: read the given text fragment and convey the characters' emotions by changing your voice in compliance with verbalised prosodic parameters; act out the dialogue modulating your voice in dependence of the characters' emotional states; read out the given text fragment imitating the personages' voices basing on their constant voice characteristics.

When having intensive integrated practice at Step 4 the students were offered integrated cluster tasks. With the tasks set we motivated students to improve the skills of decoding linguistic units nominating voice prosodic characteristics and their combinations for philological reading as well as specific skills in voice modulation. What follows are some examples of the tasks suggested: (1) Read the given part of the novel "The Great Gatsby" by F. S. Fitzgerald and pick out the descriptions of Daisy's voice characteristics. Do Daisy's voice characteristics match the descriptions of her appearance? Analyse Daisy's voice characteristics and give your opinion on her inner qualities. How do Daisy's voice characteristics reflect her personality? What are your first and final impressions of this character? How have the personage's voice characteristics influenced your impressions? Portray the character. Orally interpret the fragment. (2) Read the given extracts from "Bridget Jones's Diary" by H. Fielding. Pick out the descriptions of the lawyer's professional voice. Name a typical prosodic characteristic of a lawyer's voice you have noted down. Analyse the semantic components of the lexical units that verbalise these characteristics. Orally interpret the excerpts.

In order to avoid the monotony in learning various classroom and self-guided activities were implemented during empirical training, predominant being individual tasks, pair and small-group work. In particular, as an assignment for small-group work, students were to listen to the voice samples of belleslettres texts read for recording by native speakers, describe the voice prosodic characteristics and the emotions they express, and compare their findings with the results obtained by the group-mates. Similar activity was initiated on the basis of written discourse samples. Another classroom activity suggested describing the characters' appearance and inner qualities basing on their voice characteristics within small groups with a subsequent discussion of the created descriptions with other groups. As an assignment for selfguided individual work the students were offered to find an excerpt from a book of an English writer, pick out the professional voice (teacher's professional voice, lawyer's professional voice, policeman's professional voice, "political" voice, "military" voice), compile the list of words used in the voices' descriptions, use the obtained vocabulary to determine the main prosodic characteristics of chosen "professional voice" and read the fragment out in the form of YouTube video.

Peer interaction activity was implemented in Step 3 and Step 4. While the students performed their oral interpretation tasks, their group-mates were to fill in the chart in which they noted the correctness of correlation between the voice prosodic characteristic and the emotional state expressed by it; the precision of the character's appearance's description based on their voice prosodic parameters; the similarity of the obtained vocabularies of verbalised national/professional voices' prosodic characteristics, etc. This activity provided the practice of perception and critical evaluation as well as interactive feedback.

Characteristic of work at each Step was a reflection that suggested self-assessment checklists and summative reflective discussion. Reflective discussion conducted at the end of each lesson provided the opportunity to re-consider and sum up their work results. Students were given a list of questions for reflection, for example: What are typical means of single voice prosodic parameter (loudness, speech melody, voice quality, tempo) verbalisation? How do they reflect negative or positive associations existing in the English speaking community? What difficulties did you meet while orally interpreting the excerpt? Besides the students were to orally comment on difficulties they met with. At the beginning of the Step, they 
were offered self-assessment checklists (following the idea of self-monitoring positive influence on students' motivation by Panadero, Jonsson \& Botella, 2017) and were to fill them in before starting their work at the next Step.

The aim of the final stage of the experiment was to check the efficiency of the suggested teaching algorithm by measuring the values of specific skills in voice modulation development on the basis of the English vocabulary of verbalised voice prosodic characteristics in the belles-lettres discourse. The tasks set and grading scale were similar to the entry testing.

To elucidate students' thoughts of their own progress in the English voice production they were also offered questionnaires for self-assessment. The students were asked to rate their level of the knowledge and skills obtained on a 5-level Likert scale: Very poor - Poor - Sufficient - Good - Very good. The knowledge and skills offered for evaluation were as follows: ability to recognise English voice prosodic characteristics in oral discourse; ability to recognise the means of verbalisation of the English voice prosodic characteristics in written discourse; ability to decode single prosodic characteristics (loudness, melody, voice quality, tempo) implied in the author's remarks; ability to decode combinations of the prosodic characteristics implied in the author's remarks; ability to define the function of verbalised prosodic characteristics and their combinations in the belles-lettres texts; ability to discriminate the speaker's emotional state conveyed by their voice prosodic characteristics; ability to convey the emotional states in English by modulating their voices; ability to identify the speaker's socio-cultural characteristics (age, gender, nationality, profession, personal qualities) implied in their voice prosodic parameters; ability to vocally convey prosodic parameters in English according to the given sociocultural characteristics.

Data analysis. At the diagnostic stage, the data obtained via expert assessment of students' testing results were analysed to define the initial levels of students' specific skills in English voice modulation for oral interpretation (the criteria are described above). Mathematical processing of obtained data was used to calculate the mean proficiency coefficient (Bespalko, 1989) of students in EG 1 and EG 2. To ascertain the possibility of conducting experimental teaching the initial levels of skills in students EG 1 and EG 2 were compared employing Pearson fitting criterion. At the checkout stage, the data were mathematically calculated to indicate the changes in the levels of EG 1 and EG 2 students' specific proficiency in the English speaking voice production for oral interpretation, t-criterion of Student was employed for two independent samples to verify the data. The questionnaire for self-assessment was used to corroborate the data provided by test results It included 9 items (the abilities developed with the help of four-stepped teaching algorithm in "Oral interpretation of the text") which students were to rate on a 5-level Likert scale: Very poor - Poor Sufficient - Good - Very good. Pedagogical observation was used to reveal how the educational effect was realised.

Ethical principles of research. Participants of the experimental groups voluntarily agreed to participate in the study by signing their consents for data processing and participation. They had a possibility to withdraw without any consequences on their status.

\section{Results}

The hypothesis of the research was that suggested four-stepped teaching algorithm in "Oral interpretation of the text" would result in a considerable increase of the students' specific proficiency in the English voice production. This section provides the results we obtained via the experimental teaching.

The results of entry testing are shown in Table 1.

Table 1. Mean values of entry testing

\begin{tabular}{|c|c|c|}
\hline Index of the group & $\begin{array}{c}\text { Mean number in points } \\
\text { (Max. 36) }\end{array}$ & Mean proficiency coefficient \\
\hline EG 1 & 13.1 & 0.44 \\
\hline EG 2 & 12.8 & 0.43 \\
\hline
\end{tabular}

Following Bespalko (1989), it is sufficient to have mean proficiency coefficient more or equal to 0.7 $(\mathrm{C} \geq 0.7)$. However, as can be seen in Table 1 the obtained mean proficiency coefficients in EG 1 and EG 2 indicate students' low level of employing relevant prosodic means by appropriately modulating their voices in oral interpretation. According to the entry testing results, the obtained mean proficiency coefficients in EG 1 was 0.44 , in EG $2-0.43$, respectively. All participants of the experimental teaching (60 students, 100\%) demonstrated that the proficiency coefficient of 0.7 was not achieved. Thus, the necessity of developing students' specific proficiency in the English speaking voice production for oral interpretation was proved. To ascertain the possibility of conducting experimental teaching the initial levels of skills in students EG 1 and 
EG 2 were compared. Groups are ready to conduct experimental training in case they have the same level of proficiency. Thus, to verify this level the $\chi 2$-criterion of Pearson (Pearson fitting criterion) was employed. Output result showed that there is no difference in specific proficiency in the English speaking voice production levels of students in EG 1 and in EG 2 and these groups are ready for the experiment.

The changes in the levels of students' specific skills in English voice modulation for oral interpretation are shown in Table 2 .

Table 2. A comparative table of mean values of entry testing and final testing

\begin{tabular}{|c|c|c|c|}
\hline \multirow{2}{*}{ Index of the group } & \multicolumn{2}{|c|}{ Mean proficiency coefficient } & \multirow{2}{*}{ Increase } \\
\cline { 2 - 3 } & Entry testing & Final testing & 0.37 \\
\hline EG 1 & 0.44 & 0.81 & 0.31 \\
\hline EG 2 & 0.43 & 0.74 & \\
\hline
\end{tabular}

The results of checkout showed that the suggested teaching algorithm resulted in a considerable increase of students' abilities of employing relevant prosodic means by appropriately modulating their voices in both groups. The students of both EG 1 and EG 2 have achieved a sufficient level of proficiency by Bespalko (1989) - the mean coefficient of proficiency was more $0.7(\mathrm{C} \geq 0.7)-0.81$ and 0.74 , respectively. However, students of EG 2 have demonstrated a less significant increase of the specific proficiency in the English speaking voice production - 0.31 in comparison with EG 1 (0.37).

To verify the obtained data, t-criterion of Student was employed for two independent samples. Two hypotheses were formulated: $\mathrm{H} 0$ : at the end of the experimental teaching significant results could not be achieved, i.e. there is no significant difference between results of students in EG 1 and EG 2; H1: differences in students of EG 1 and EG 2 are statistically significant in favour of EG 1, i.e. the learning model, tested in EG 1, is more effective. Thus, the mean result in EG 1 is higher than in EG 2 with test significance $\alpha=0,05$ (which is typical for pedagogical research). The calculations showed that $t_{\mathrm{emp}}=2.4, \mathrm{t}_{\mathrm{cr}}=2$. Since the condition for accepting hypothesis $\mathrm{H}_{1}$ is the ratio $\mathrm{t}_{\mathrm{emp}} \geq \mathrm{t}_{\mathrm{cr}}$, therefore, the difference between the means (final testing results) for the compared samples can be considered proven.

Data analysis of the effectiveness of two learning models with the help of t-criterion revealed that the mean difference in the levels of proficiency coefficient in students of EG 1 and EG 2 is significant. This allowed us to make a conclusion that with the suggested algorithm being effective for developing pre-service English teachers' skills of decoding verbalised vocal cues in order to bring their voices as close to the English speaking voice as possible and employing relevant prosodic means in oral interpretation of the text, the first variant of the learning model is more appropriate.

The entry test results revealed that both tasks were rather challenging for the students of EG 1 and EG 2 as they did not comprehend clearly English voice phenomenon, its main constituents and functions, were not aware of their verbalisation means. Thus, the students were not able to decode the prosodic characteristics implied in the authors' remarks in the English belles-lettres fragments and consequently to modulate their voices in oral interpretation, though they recognised the emotional states or personages' social characteristics due to the given micro-contexts.

The results of final testing showed that in both EG 1 and EG 2 starting the mechanism of the English voice perception by introducing the basic issues and precisely following the four Steps of our teaching algorithm was a success. Being provided with the instructions and special tasks aimed at developing analytical, productive and integrated skills during the empirical training the students came to understanding the semantic nature of linguistic units nominating voice prosodic characteristics and their combinations, learned to decode verbalised vocal cues in the process of philological reading in order to bring their voices as close to the English voice as possible in oral interpretation.

According to our observation, the most complicated task for the students of both EG 1 and EG 2 was to imitate English voice prosodic parameters independently of their functions. It is resulting from the peculiarities of the English national type of voice production which is characterised by melody modulation, wide pitch range and decreased loudness, and is conditioned by the phonetic base of a definite language. In our case, English and Ukrainian phonetic bases differ significantly.

However, output quantitative and qualitative results show the overall effectiveness of the suggested teaching algorithm for developing pre-service English teachers' skills of decoding the English vocabulary of verbalised voice prosodic characteristics and their functions in the belles-lettres discourse in order to employ appropriate prosodic means in oral interpretation of the text. 
The analysis of students' self-assessment questionnaires corroborates positive impact of the worked-out teaching algorithm. The results of students' grading of their achievements in the English voice perception and production are shown in Table 3.

Table 3. Level of students' knowledge and skills: self-assessment results

\begin{tabular}{|c|c|c|c|c|c|c|c|c|c|c|}
\hline \multirow[t]{3}{*}{ Students' knowledge and skills } & \multicolumn{10}{|c|}{ Students' self-assessment (number of students) } \\
\hline & \multicolumn{2}{|c|}{ Very poor } & \multicolumn{2}{|c|}{ Poor } & \multicolumn{2}{|c|}{ Sufficient } & \multicolumn{2}{|c|}{ Good } & \multicolumn{2}{|c|}{ Very good } \\
\hline & EG 1 & $\begin{array}{c}\text { EG } \\
2\end{array}$ & $\begin{array}{c}\text { EG } \\
1\end{array}$ & $\begin{array}{c}\text { EG } \\
2\end{array}$ & EG & $\begin{array}{c}\text { EG } \\
2\end{array}$ & EG & $\begin{array}{c}\text { EG } \\
2\end{array}$ & EG & EG 2 \\
\hline $\begin{array}{l}\text { Ability to recognise English voice prosodic } \\
\text { characteristics in oral discourse }\end{array}$ & - & - & - & - & 2 & 10 & 5 & 7 & 23 & 13 \\
\hline $\begin{array}{l}\text { Ability to recognise the means of verbalisation } \\
\text { of the English voice prosodic characteristics in } \\
\text { belles-lettres discourse }\end{array}$ & - & - & - & - & 1 & 2 & 5 & 8 & 24 & 20 \\
\hline $\begin{array}{l}\text { Ability to decode single prosodic characteristics } \\
\text { (loudness, speech melody, voice quality, tempo) } \\
\text { implied in the author's remarks }\end{array}$ & - & - & - & - & 4 & 7 & 5 & 5 & 21 & 18 \\
\hline $\begin{array}{l}\text { Ability to decode combinations of the prosodic } \\
\text { characteristics implied in the author's remarks }\end{array}$ & - & - & - & - & 5 & 7 & 7 & 8 & 18 & 15 \\
\hline $\begin{array}{l}\text { Ability to define the function of verbalised } \\
\text { prosodic characteristics and their combinations } \\
\text { in the English belles-lettres texts }\end{array}$ & - & - & - & - & 1 & 5 & 4 & 6 & 25 & 19 \\
\hline $\begin{array}{l}\text { Ability to discriminate the speaker's emotional } \\
\text { state conveyed by their voice prosodic } \\
\text { characteristics }\end{array}$ & - & - & - & - & - & 2 & 5 & 7 & 25 & 21 \\
\hline $\begin{array}{l}\text { Ability to convey the emotional states in English } \\
\text { by modulating their voices }\end{array}$ & - & - & - & - & 3 & 4 & 1 & 6 & 26 & 20 \\
\hline $\begin{array}{l}\text { Ability to identify a speaker's socio-cultural } \\
\text { characteristics (age, gender, nationality, } \\
\text { profession, personal qualities) implied in their } \\
\text { voice prosodic parameters }\end{array}$ & - & - & - & - & 6 & 8 & 4 & 5 & 20 & 17 \\
\hline $\begin{array}{l}\text { Ability to vocally convey prosodic parameters in } \\
\text { English according to the given sociocultural } \\
\text { characteristics }\end{array}$ & - & - & - & - & 5 & 8 & 4 & 4 & 21 & 18 \\
\hline
\end{tabular}

Though some differences can be seen in students of EG 1 and EG 2 self-assessment questionnaires results, it should be noted that none of the students assessed their abilities as Very Poor or Poor. This fact is supported by the final testing results and our observations.

\section{Discussion}

Results obtained further support the idea that English voice production demands specific skills in voice modulation from non-native English speakers. As language and literature teachers can be called voice professionals, it is important for students - pre-service English language and literature teachers - to be able to produce and modulate their voices as close to the English voice as possible. Our findings correspond to the scholars' idea that "the voice is a crucial element that enables the work of teachers and the knowledge that this professional has of his voice is extremely important in order to recognise its qualities and limitations, and the consequence of these in class development" (Sevilha, Fialho da Costa, 2015).

We argue the efficacy of the teaching algorithm suggested for developing pre-service English language and literature teachers' skills in decoding linguistic units that nominate voice prosodic characteristics and their combinations, and for training their specific skills in voice modulation in oral interpretation of the belles-lettres texts. On the one hand, our ideas are based on Belin's et al. (2004) model of voice perception. On the other hand, tasks realisation scheme partially corresponds to the Vovk's (2017) idea that "they [students] process the information under study by reproducing, substituting, modifying and transforming it, performing at that cognitive operations of analysis, synthesis, comparison, generalisation, induction, deduction, inference, etc., and subsequently produce their own speech output" (p. 82).

The overall results show that EG 1 and EG 2 students' skills in English voice production were gradually improving from Step 1 (introducing theoretical material) to Step 4 (integrated practice) that prove the effectiveness of our algorithm.

Pedagogical observation during empirical training showed that suggested tasks and activities allow students to learn how to produce and modulate their voices on the basis of a cognitive mechanism of English voice perception. The variety of tasks provided a sense of discovery in learning how to decode verbalised 
vocal cues in order to bring their voices as close to the English speaking voice as possible, to analyse a text in order to deep into its images, symbols, reveal its characters, and finally, communicate the results of the analysis using a voice. The use of intensive interactive practice activities promoted students' motivation and, as a result, active involvement in the interactive process of decoding the English vocabulary of verbalised voice prosodic characteristics and their functions in the belles-lettres discourse in order to employ appropriate prosodic means in oral interpretation of the text.

An effective means of metacognition was peer interaction activity which promoted peer-assessment with a critical awareness of the mechanism of the English voice perception. Being a part of the practice, feedback, evaluation process, this activity allowed students to become critically aware of their own reading aloud tasks performance, on the one hand, and to develop both professional analytical and evaluative skills, on the other. This agrees with the results of previous research works which argue a positive effect of peer interaction on students' improving learning process (Logan, 2009; Ahangari et al., 2013; Khonbi \& Sadeghi, 2013; De Grez et al., 2012; Machera, 2017; Ndoye, 2017).

According to Zadorozhna et al. (2018) "foreign language teachers can benefit from the introduction of diverse reflection tools into their training" (p. 65). Noteworthy is that reflection activities (self-assessment checklists and summative reflective discussions) were one of the main factors that helped students monitor understanding, organise their knowledge, identify and fill the gaps in their knowledge of the English speaking voice parameters verbalisation means, to assess own success of task achievement, and motivated them to improve their skills of employing relevant prosodic means in English by appropriately modulating their voices. On the one hand, it correlates with Schön's (2017) idea that that reflection bridges the theoretical and practical knowledge, therefore, changing practice; on the other hand, with Boud's et al. (1985) statement that being an intellectual and affective activity, reflection provides new understanding and appreciation.

Our conclusion that the first variant of the learning model (a wider communicative context and tasks with a graphical representation of the analysis results) is more appropriate and effective correlates with findings made in the previous research works. Constructing graphic schemes illustrating semantic components of the lexical units that verbalise various combinations of voice prosodic characteristics proved to be effective enough in the cognitive process of decoding their meaning as there is a strong interconnection between language and visual perception. Visual perception provides the language with information, activates language-related stimuli and starts cognitive mechanisms of language processing (Vulchanova et al., 2019; Mani \& Plunkett, 2010). Students who use graphic organisers that present information in a visual form display better results than those who do not, as such tasks stimulate their cognitive activity (Van Meter et al., 2016).

Noteworthy is the positive effect of work with both written and oral fragments for developing preservice English language and literature teachers' skills in decoding and orally interpreting verbalised English voice prosodic characteristics. It is explained by the fact that auditory perception correlates with language processing and has a potential influence on the efficiency of language acquisition (Diaz et al., 2008; Mueller et al., 2012). Extrapolating these findings on our study we claim that stimulating students' auditory perceptual abilities resulted in sufficient improvement of their vocal skills while training their voices sound English.

A major implication of our research findings is the necessity for educators to further pursue to train preservice English teachers in mastering their voices in order to make them sound English. To achieve this goal, it is rational to focus on starting in students the mechanism of English voice perception. For this purpose, considering the positive influence of the suggested teaching algorithm for students' specific proficiency in the English voice production they can be used as a guideline to overcome difficulties in training professional voices of pre-service English language and literature teachers.

\section{Limitations}

It is mandatory to emphasise that our methodology has got certain limitations as it is intended only for students who study English for professional purpose and demands C 1 level in English. However, the obtained results can be extrapolated to the study of any foreign language for professional purpose.

\section{Conclusions}

As it was hypothesised the suggested teaching algorithm considerably increased students' proficiency in the English voice production. The major point of our study is that due to the consistent teaching procedures including four steps within the course "Oral interpretation of the text" we managed to start in students the mechanism of English voice perception which resulted in their acquiring an ability to decode verbalised voice prosodic characteristics and their functions in the process of philological reading and finally to develop 
pre-service English language and literature teachers' specific skills in English voice modulation in oral interpretation.

To conclude, it is obvious that proper foreign language education is impossible without profound comprehending fundamental peculiarities of voice production in a studied foreign language, its means of verbalisation and as a final goal a foreign-speaking voice acquisition. Thus, the suggested teaching algorithm can be of use in the study of any foreign language. As for the perspectives of our research work, there is still a wide field for searching various effective ways and teaching tools to achieve practical benefits in developing flexible and expressive voices in pre-service English language and literature teachers, in particular in complex with visual non-verbal cues.

\section{References:}

Ahangari, S., Rassekh-Alqol, B., \& Hamed, L. A. A. (2013). The effect of peer assessment on oral presentation in an EFL context. International Journal of Applied Linguistics and English Literature, 2(3), $45-53$. https://doi.org/10.7575/aiac.ijalel.v.2n.3p.45

Belin, P., Fecteau, Sh. \& Bedard, C. (2004). Thinking the voice: neural correlates of voice perception. TRENDS in Cognitive Sciences, 8(3), 129-135. https://doi.org/10.1016/j.tics.2004.01.008

Bespalko, V. P. (1989). Slagaemye pedagogicheskoj tehnologii [Components of pedagogical technology]. Moscow: Pedagogika. Retrieved 20 March 2020 from https://www.klex.ru/author/bespalko/

Boud, D., Keogh, R. \& Walker, D. (1985). Reflection: Turning experience into learning. London: Routledge. https://doi.org/10.4324/9781315059051

Cooper, J. (1992). Polo. London: Corgi Books.

De Grez, L., Valcke, M., \& Roozen, I. (2012). How effective are self- and peer assessment of oral presentation skills compared with teachers' assessments? Active Learning in Higher Education, 13(2), 129-142. https://doi.org/10.1177/1469787412441284

Diaz, B., Baus, C., Escera, C., Costa, A., \& Sebastián-Gallés, N. (2008). Brain potentials to native phoneme discrimination reveal the origin of individual differences in learning the sounds of a second language. Proc Natl Acad Sci USA, 105, 16083-16088. https://doi.org/10.1073/pnas.0805022105

Demchuk, A. (2009). Osnovnye prosodicheskie parametry rechevogo golosa I sredstva ih verbalizatsii v angliyiskom yazyke [Main prosodic parameters of the speaking voice and its verbalisation means in the English language (on the basis of dictionaries and belles-lettres texts)]. Zapysky z romano-germaskoyi philologii, 23, 18-25. Retrieved 10 September 2020 from http://liber.onu.edu.ua/pdf/zap_rgf_23.pdf

Demchuk, A. (2015). Sredstva verbalizatii sochetaemosti prosodicheskih kharakteristic rechevogo golosa v sovremennom anglyiskom yazyke [Means of the speaking voice prosodic characteristics combinatory verbalisation in the modern English language]. Odesky lingvistychnyi visnyk, 6 (2), 9-12. https://doi.org/10.32837/olj.v2i6.310

Derry, S. J. (1990). Learning strategies for acquiring useful knowledge. In B. F. Jones \& L. Idol (Eds.), Dimensions of thinking and cognitive instruction (pp. 347-379). Hillsdale, NJ: Lawrence Erlbaum Associates https://doi.org/10.4324/9780203771686

Fielding, H. (1999). Bridget Jones's diary. London: Picador.

Kain, P. (1998). How to do a close reading. Harvard College Writing Center. Retrieved 10 June 2020 from https://writingcenter.fas.harvard.edu/pages/how-do-close-reading

Khonbi, Z. A. \& Sadeghi, K. (2013). The effect of assessment type (self vs. peer) on Iranian University EFL students' course achievement. Procedia - Social and Behavioral Sciences, 70, 1552-1564. Retrieved 25 May 2020 from https://www.sciencedirect.com

King, S. (1999). Green mile. New York: Pocket book.

Klug, D. (2015). Tell me a Story: Oral Interpretation in the English Classroom. Annals of Foreign Studies, 90, 119-134. Retrieved 10 June 2020 from https://core.ac.uk/download/pdf/48513684.pdf

Logan, E. (2009). Self and peer assessment in action. Practitioner Research in Higher Education, 3(1), 29-35. Retrieved 21 June 2020 from https://files.eric.ed.gov/fulltext/EJ1130670.pdf

Machera, R. P. (2017). Teaching intervention strategies that enhance learning in higher education. Universal Journal of Educational Research, 5(5), 733-743. https://doi.org/10.13189/ujer.2017.050505

Mani, N., \& Plunkett, K. (2010). In the infant's mind's ear: Evidence for implicit naming in 18-month-olds. Psychological Science, 21(7), 908-913. https://doi.org/10.1177/0956797610373371

Mueller, L. J., Friederici, A., \& Männel, C. (2012). Auditory perception at the root of language learning. Proc Natl Acad Sci U S A., 109(39), 15953-15958. http://doi:10.1073/pnas.1204319109

Ndoye, A. (2017). Peer/self-assessment and student learning. International Journal of Teaching and Learning in Higher Education, 29 (2), 255-269. Retrieved 19 June 2020 from https://files.eric.ed.gov/fulltext/EJ1146193.pdf

Panadero, E., Jonsson, A. \& Botella, J. (2017). Effects of self-assessment on self-regulated learning and self-efficacy: Four metaanalyses. Educational Research Review, 22, 74-98. https://doi.org/10.1016/j.edurev.2017.08.004

Perlova, O. V. (2015). The role of linguistic and cross-cultural reading in teaching foreign languages to future sociologists. Vestnik of MSLU, 4 (715), 89-93. Retrieved 22 June 2020 from http://www.vestnik-mslu.ru/Vest/Vest15-715zc.pdf

Perlova, O. V. (2016). Razvitie professionalno kommunikativnyh umeniyi u studentov yazykovogo VUZa [Developing professionally communicative skills of linguistics students in higher education institutions]. Vestnik of MSLU, 2 (766), 4448. Retrieved 15 October 2020 from http://www.vestnik-mslu.ru/Vest/2_766_obr.pdf

Rabiah, E. (2020). Lexical measures for testing progress in Hebrew as Arab students' L2. Journal of Language and Linguistic Studies, 16 (3), 1096-1114. https://doi.org/10.17263/jlls.803551

Schön, D. (2017). The Reflective Practitioner: How professionals think in action. London: Routledge. https://doi.org/10.4324/9781315237473 
Sevilha, E. \& da Costa, A. (2015). Knowledge about voice and the importance of voice as an educational resource in the perspective of university professors. Revista CEFAC, $17(1)$. Retrieved 17 June 2020 from http://dx.doi.org/10.1590/19820216201514813

Zadorozhna I., Datskiv O., Levchyk N. (2018). Development of pre-service foreign language teachers' emotional intelligence by means of reflection. Advanced Education, 10, 62-68. https://doi.org/10.20535/2410-8286.144538

Van Meter, P. N., Firetto, C. M., Turns, S. R., Litzinger, T. A., Cameron, C. E., Shaw C. W. (2016) Improving Students' Conceptual Reasoning by Prompting Cognitive Operations. Journal of Engineering Education, 105 (2). 245277. https://doi.org/10.1002/jee.20120

Vovk, O. (2017). Foreign language acquisition: a communicative and cognitive paradigm. Science and Education, 6, 81-85. https://doi.org/10.24195/2414-4665-2017-6-13

Vulchanova, M., Vulchanov, V., Fritz, I., \& Milburn E. (2019). Language and perception: Introduction to the Special Issue "Speakers and Listeners in the Visual World". Journal of Cultural Cognitive Science, 3, 103-112. https://doi.org/10.1007/s41809-01900047-z

Yakovleva, E. V. (1998). Kategoriya ekspressivnosti chteniya kak filologicheskaya problema [Category of expressive reading as a philological problem]. Yazyk, soznanie, komminikatsiya, 3, 102-109. Retrieved 10 May 2020 from http://www.philol.msu.ru/ slavphil/books/jsk_03_12jakovleva.pdf 